\title{
PEMANFAATAN BUNGKIL JAGUNG DALAM PENGOMPOSAN PELEPAH KELAPA SAWIT
}

\section{UTILIZATION OF CORN PREVENTION IN THE COMPOST OF PALM OIL PLANT}

\author{
Dina Arfianti Saragih ${ }^{1}$, Ingrid Ovie Yosephine Sitompul ${ }^{1}$ dan Iqbal Mariandi Rambe ${ }^{1}$ \\ ${ }^{1}$ Program studi Budidaya Perkebunan, Sekolah Tinggi Ilmu Pertanian Agrobisnis Perkebunan (STIP-AP), \\ Jl. Williem Iskandar, Medan 20226
}

Email : dinaarfiantisaragih.das@gmail.com

\begin{abstract}
ABSTRAK
Tanaman kelapa sawit memiliki limbah seperti pelepah kelapa sawit yang dapat digunakan sebagai nutrisi tanaman dalam bentuk kompos. Untuk mempercepat proses pengomposan pelepah kelapa sawit dapat diberikan penambahan tepung jagung sebagai nutrisi mikroorganisme yang berperan dalam mendegradasi daun kelapa sawit. Penelitian ini bertujuan untuk mengetahui perbandingan kompos $\mathrm{C} / \mathrm{N}$, kompos C-Organik, kandungan nitrogen kompos, dan lama pengomposan daun kelapa sawit. Penelitian ini menggunakan metode deskriptif dengan 5 perlakuan: kontrol P0 (pelepah 2kg), P1 (pelepah $2 \mathrm{~kg}$ dan tepung jagung 0,2 kg), P3 (pelepah $2 \mathrm{~kg}$ dan tepung jagung 0,4 kg), P4 (pelepah $2 \mathrm{~kg}$ dan $0,6 \mathrm{~kg}$ tepung jagung), P5 (2 kg pelepah dan $0,8 \mathrm{~kg}$ makanan inti). Hasil penelitian menunjukkan bahwa suhu dan $\mathrm{pH}$ kompos dari daun kelapa sawit sesuai dengan Standar Nasional Indonesia. Hasil peengomposan kadar C-Organik tertinggi terdapat pada komposisi 0,6 kg tepung jagung dengan $2 \mathrm{~kg}$ pelepah daun sawit dengan nilai 40,11\% dan terendah ditemukan pada pemberian $0,8 \mathrm{~kg}$ tepung jagung pada $2 \mathrm{~kg}$ pelepah daun kelapa sawit dengan nilai $37,27 \%$. Kandungan nitrogen tertinggi ditemukan pada P3 dengan pemberian tepung jagung $0,4 \mathrm{~kg}$ pada $2 \mathrm{~kg}$ pelepah daun sawit dengan nilai 2,61\% sementara nilai terendah pada P1 dengan penambahan 0,2 $\mathrm{kg}$ tepung jagung pada $2 \mathrm{~kg}$ pelepah dengan nilai 1,97\%. Hasil rasio $\mathrm{C} / \mathrm{N}$ tertinggi dijumpai pada $\mathrm{P} 2$ (tepung jagung $0,2 \mathrm{~kg}$ pada pelepah $2 \mathrm{~kg}$ daun sawit dengan nilai $20,10 \%$ dan nilai terendah pada perlakuan P3 pada pemberian 0,6 kg tepung jagung pada $2 \mathrm{~kg}$ pelepah daun sawit dengan nilai $14,92 \%$.
\end{abstract}

\begin{abstract}
Oil palm plants have wasted such as oil palm leaves which can be used as plant nutrients in the form of compost. In order to accelerate the process of composting palm oil leaves can be given the addition of cornflour as a nutrient for microorganisms that play a role in accelerating the decomposition of palm oil leaves. This study aims to determine the ratio of $\mathrm{C}$ / N compost, C-Organic compost, compost nitrogen content, and composting time of palm oil leaves. This research uses descriptive method with 5 treatments: P0 control (2 kg midrib), P1 ( $2 \mathrm{~kg}$ midrib and $0.2 \mathrm{~kg}$ corn flour), P3 ( $2 \mathrm{~kg}$ midrib and $0.4 \mathrm{~kg}$ corn starch), P4 (2 kg midrib and $0,6 \mathrm{~kg}$ of corn flour), P5 (2 kg of midrib and $0.8 \mathrm{~kg}$ of core food). The results showed that the compost temperature and $\mathrm{pH}$ of palm oil leaves were in accordance with Indonesia Standard. The results of the C-Organic content obtained the highest C-Organic content found in the composition of $0.6 \mathrm{~kg}$ of cornflour with $2 \mathrm{~kg}$ of palm leaf midrib with a value of $40.11 \%$ and the lowest was found in the administration of $0.8 \mathrm{~kg}$ of cornflour in $2 \mathrm{~kg}$ of palm
\end{abstract}


leaf midrib with a value of $37.27 \%$. The highest nitrogen content was found in $\mathrm{P} 3$ by giving $0.4 \mathrm{~kg}$ of cornflour to $2 \mathrm{~kg}$ of palm leaf midrib with a value of $2.61 \%$ while the lowest value was in P1 by adding $0.2 \mathrm{~kg}$ of cornflour to $2 \mathrm{~kg}$ of midrib with a value of $1.97 \%$. The highest $\mathrm{C} / \mathrm{N}$ ratio results were found in $\mathrm{P} 2(0.2 \mathrm{~kg}$ corn flour on $2 \mathrm{~kg}$ palm fronds with a value of $20.10 \%$ and the lowest value on P3 treatment at $0.6 \mathrm{~kg}$ of corn flour on $2 \mathrm{~kg}$ palm fronds with a value of $14.92 \%$.

Keywords: Palm fronds, Corn meal, Decomposition of palm fronds.

\section{PENDAHULUAN}

Tanaman kelapa sawit (Elaeis guineensis Jacq) memiliki arti penting bagi pembangunan nasional. Indonesia juga merupakan negara produsen minyak kelapa sawit terbesar di dunia. Pada tahun 2017 tercatat pada Data Statistik Perkebunan Komoditas Kelapa Sawit, Indonesia memiliki total luas areal 12.307.227 Ha dan memproduksi minyak sawit sebesar 35.359.384 ton. Indonesia menjadi pemain utama dalam pasar sawit dunia karena mampu memenuhi $54,4 \%$ dari total ekspor minyak sawit dunia (Ditjenbun, 2017). Selain itu tanaman kelapa sawit juga mengeluarkan limbah salah satunya pelepah kelapa sawit. Jumlah limbah yang dikeluarkan semakin meningkat sejalan dengan pertumbuhan produksi kelapa sawit. Limbah pertanian meliputi semua hasil dari proses pertanian yang tidak termanfaatkan atau belum memiliki nilai ekonomis. Salah satu limbah dari perkebunan kelapa sawit adalah pelepah daun. Apabila limbah daun pelepah kelapa sawit ini tidak di manfaatkan dapat menjadi masalah lingkungan di sekitar perkebunan (Risza, 2010).

Salah satu cara untuk memanfaatkan pelepah daun kelapa sawit sebagai unsur hara tanaman adalah dalam bentuk kompos. Proses pengomposan pelepah kelapa sawit dapat dipercepat dengan menggunakan bantuan Effevtive Microorganisme (EM4) yang mampu mempercepat kematangan kompos. EM4 mampu mempercepat proses dekomposisi bahan organik dan meningkatkan ketersedian hara bagi tanaman serta telah diterapkan pada berbagai jenis tanaman dan kondisi tanah (Yuwono, 2007). Selain itu masih ada limbah pengolahan minyak kelapa sawit yaitu sisa kernesl yang bermanfaat sebagai aktivator dalam proses pengomposan biomassa limbah seperti pelepah dan daun sawit, tandan kosong kelapa sawit, juga limbah pertanian lainnya. Seperti yang dilaporkan oleh Jeremi, 2018 memanfaatkan palm kernel cake (PKC) sebagai sumber makanan bagi mikroorganisme dalam pengomposan pelepah kelapa sawit. Kandungan zat-zat makanan PKC yaitu protein kasar 15,40\%, lemak kasar 6,49\%, serat kasar 19,62\%, Ca $0,56 \%$, P $0,64 \%$.

Industri pengolahan minyak lainnya yang juga mengeluarkan limbah yaitu pengolahan minyak jagung. Bungkil jagung sebagai limbah yang biasanya dimanfaatkan dalam meningkatkan gizi pakan ternak. Komposisi gizi limbah minyak jagung ( $\%$ BK) adalah sebagai berikut: BK 88,06\%, Abu 11,10\%, Protein Kasar 21.89\%, Lemak $0.33 \%$, Serat Kasar $8.9 \%$, Beta-N 53.10\%, $\mathrm{Ca} 0.06 \%$, dan $\mathrm{P} 2.18 \%$. Bungkil jagung digunakan sebagai sumber energi untuk ternak.

Selain sebagai pakan ternak, bungkil jagung ini dapat digunakan sebagai aktivator dalam proses pengomposan biomassa seperti pelepah daun kelapa sawit. Bungkil jagung dan PKC sama-sama memiliki kandungan gizi yang tinggi 
sehingga masih dapat dimanfaat sebagai sumber nutrisi bagi aktivitas mikroorganisme yang berperan dalam pengomposan pelepah kelapa sawit.

\section{METODE PENELITIAN}

Tempat dan Waktu Penelitian

Penelitian ini dilaksanakan di rumah kaca Sekolah Tinggi Ilmu Pertanian Agrobisnis Perkebunan (STIPAP) dan analisis laboratorium dilakuan di PT. SOCFINDO pada bulan April - Juli 2019.

Penelitian ini dilakukan dengan
metode deskriftif karena sebagai
perbandingan antara bungkil jagung dan
PKC dengan menambahkan dosis pada
bungkil jagung untuk mempercepat proses
pengomposan pelepah kelapa sawit.

Penelitian ini terdiri dari 5 perlakuan yaitu :

P0 : Kontrol (2 kg pelepah)

P1 : $2 \mathrm{~kg}$ pelepah dan $0,2 \mathrm{~kg}$ bungkil jagung

P2 : $2 \mathrm{~kg}$ pelepah dan $0,4 \mathrm{~kg}$ bungkil jagung

P3 : $2 \mathrm{~kg}$ pelepah dan $0,6 \mathrm{~kg}$ bungkil jagung

P4 : $2 \mathrm{~kg}$ pelepah dan $0,8 \mathrm{~kg}$ bungkil jagung

Jumlah Perlakuan $=5$

Jumlah Ulangan $=5 \mathrm{x}$

Total $=25$

\section{Pengamatan dan Indikator}

1. Suhu, dilakukan $1 \times 1$ minggu dilakukan sebelum pembalikan dengan menggunakan thermometer.

2. $\mathrm{PH}$, dilakukan $1 \times 1$ minggu dilakukan sebelum pembalikan dengan menggunakan $\mathrm{PH}$ meter.

3. Kadar C-Organik dan Nitrogen kompos, dilakukan diakhir pengomposan.

4. Rasio $\mathrm{C} / \mathrm{N}$ dilakukan diakhir pengomposan.

5. Lama waktu pengomposan.

\section{HASIL DAN PEMBAHASAN}

Suhu

Suhu merupakan faktor utama yang mempengaruhi aktivitas mikroorganisme dalam proses pengomposan (Epstein, 1997).

Suhu merupakan penentu dalam aktivitas dekomposisi. Disamping itu juga untuk mengetahui bagaimana proses dekomposisi berjalan. Suhu awal pada saat penelitian $28^{\circ}-29^{\circ} \mathrm{C}$. Rendahnya suhu awal kompos diduga akibat belum terjadinya proses dekomposisi.

Suhu kompos mengalami fluktuasi (peningkatan dan penurunan) suhu yang berbeda. Aktivitas dekomposisi oleh mikroba di dalam kompos dengan menggunakan oksigen akan menguraikan bahan organik menhadi $\mathrm{CO}_{2}$, uap air dan panas (Isroi, 2008).

Minggu pertama setelah perlakuan suhu pengomposan pelepah kelapa sawit naik sekitar $2^{\circ} \mathrm{C}$ dari suhu awal menjadi $30^{\circ} \mathrm{C}$ dan pada minggu kedua terjadi kenaikan suhu kompos sekitar $3^{\circ} \mathrm{C}$ dari suhu minggu pertama $\quad 33^{\circ}-37^{\circ} \mathrm{C}$. Pada kondisi ini terjadi penguraian bahan organik yang sangat aktif. Kenaikan suhu tersebut menandakan adanya aktivitas mikro organisme sehingga menghasilkan sejumlah energi dalam bentuk panas yang ditandai dengan meningkatnya suhu kompos.

Proses

pengomposan mikroorganisme melepaskan energi panas yang merupakan produk dari proses karbonasi. Pada saat terjadi penguraian bahan organik yang sangat aktif, mikrobamikroba yang ada di dalam kompos akan menguraikan bahan organik (Fanny, 2013).

Minggu ketiga terjadi penurunan suhu sekitar $2^{\circ} \mathrm{C}$ dari suhu kompos minggu kedua menjadi $32-35^{\circ} \mathrm{C}$. Hal diakibat kan 
keadaan kompos yang terlalu lembab sehingga air yang di dalam kompos tidak dapat turun dan menguap maka dilakukan pembalikan pada kompos.

Minggu keempat suhu kompos menigkat kembali dengan suhu rata-rata 33$38^{\circ} \mathrm{C}$. Peningkatan suhu kompos terjadi karena kelembaban yang terjaga maka mulailah aktivitas mikroorganisme mendekomposisi bahan organik.

Minggu kelima sampai pada akhir pengamatan terjadi penurunan suhu yang signifikan. Penurunan suhu ini dikarenakan aktivitas mikroorganisme mulai menurun, Maka suhu kompos akan berangsur-angsur mengalami penurunan pada tahap yang disebut pendinginan atau fase pematangan dimana konsentrasi bahan organik pada kompos sudah menipis jumlahnya. Penurunan jumlah dan aktivitas mikroba menyebabkan suhu tidak meningkat lagi dan relatif stagnan (Wahyono $d k k, 2011$ ).

Perubahan suhu kompos pelepah kelapa sawit disajikan pada gambar 4.1 dibawah:

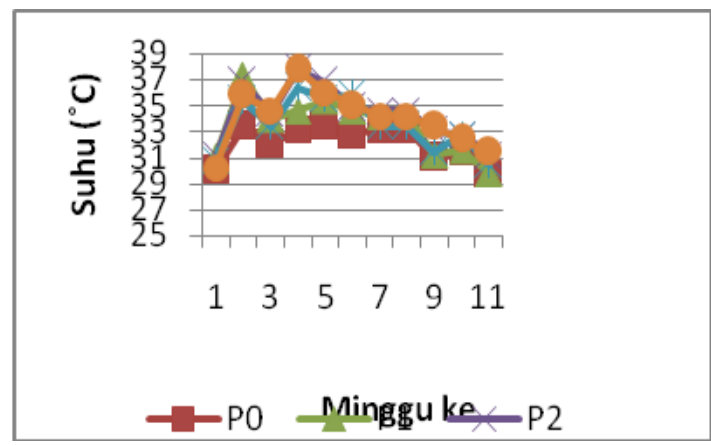

Menurut Indriani (2007), suhu optimal dalam proses pengomposan adalah 30$50^{\circ} \mathrm{C}$, sedangkan menurut kriteria SNI (BSN 2004), suhu ideal proses pengomposan maksimal $50^{\circ} \mathrm{C}$. Peningktan suhu terjadi karena aktivitas bakteri dalam mendekomposisi bahan organik.

\section{pH}

Pengamatan $\mathrm{pH}$ pengomposan pelepah kelapa sawit selama 11 minggu perlu dilakukan karena merupakan salah satu faktor yang kritis bagi pertumbuhan mikroorganisme yang terlibat dalam proses pengomposan.

Minggu pertama pada perlakuan P0, $\mathrm{P} 1$ menunjukkan $\mathrm{pH}$ basa hal ini dikarenakan bahan oragnik masih segar dan belum terombak oleh mikroba dan pada perlakuan P2, P3, P4 menunjukkan $\mathrm{pH}$ asam hal ini di karenakan terjadi proses perombakan dari bahan organik menjadi asam-asam organik oleh mikroba.

Minggu kedua terjadi penurunan $\mathrm{pH}$ pada perlakuan P0 menunjukkan basa karena pada perlakuan P0 tidak diberi bungkil jagung sedangkan pada perlakuan P2, P3, P4 menunjukkan asam terjadinya aktivitas mikroba merombak bahan organik sehingga $\mathrm{pH}$ menurun. Penurunan $\mathrm{pH}$ juga diikuti oleh bau yang ditimbulkan pada kompos karena suasana asam.

Minggu ketiga dan keempat terjadi kenaikan $\mathrm{pH}$ pada perlakuan P0, P1, P2, P3, P4 menunjukkan basa hal ini menandakan aktivitas mikroba mulai menurun karena berkurangnya bahan-bahan organik yang dibutuhkan.

Menurut Buckman dan Brady (1982), bahwa hasil proses dekomposisi bahan organik oleh mikroorganisme mengahsilkan ion $\mathrm{OH}^{-}$sehingga menunjang peningkatan kebasaan yang selanjutnya meningkatkan nilai $\mathrm{pH}$ kompos tersebut.

Minggu kelima sampai akhir penelitian terjadi penurunan $\mathrm{pH}$ basa hal ini menandakan bahwa aktivitas mikroba dalam menghasilkan asam-asam organik masih berjalan.

Perubahan $\mathrm{pH}$ kompos berawal dari $\mathrm{pH}$ agak asam karena terbentuknya asam-asam organik sederhana, kemudian $\mathrm{pH}$ meningkat pada inklubasi lebih lanjut akibat terurainya protein dan terjadi pelepasan ammonia. Penigkatan dan penurunan $\mathrm{pH}$ juga merupakan penanda terjadinya aktivitas 
miroorganisme dalam menguraikan bahan organik (Firdaus, 2011).

Menurut Astri (2011) nilai pH yang berada di kisaran netral akan mudah dan digunakan tanaman, serta berguna untuk mengurangi keasaman tanah karena sifat asli tanah adalah asam. Adapun Perubahan $\mathrm{pH}$ selama proses dekomposisi disajikan pada gambar 4.2 dibawah :

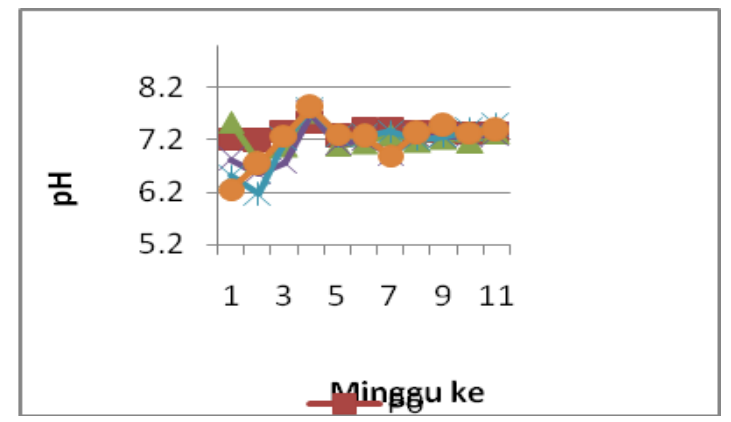

pH kompos yang ideal berdasarkan standar kualitas kompos SNI:19-7030-2004 berkisar antara 6,80-7,49. Menurut Marlina (2009), pH material kompos bersifat asam pada awal pengomposan. Bakteri pembentuk asam akan menurunkan $\mathrm{pH}$ sehingga kompos bersifat lebih asam. Selanjutnya mikroorganisme mulai mengubah nitrogen anorganik menjadi amonium sehingga $\mathrm{pH}$ meningkat dengan cepat menjadi basa. Sebagian ammonia dilepaskan atau dikonversi menjadi nitrat dan didenitrifikasi oleh bakteri sehingga $\mathrm{pH}$ kompos menjadi netral.

\section{Kadar C-Organik Kompos Pelepah Kelapa Sawit.}

Menurut (Mirwan, 2015), COrganik merupakan indikator telah terjadinya proses dekomposisi dalam pengomposan dan kematangan kompos. Kadar karbon cenderung mengalami penurunan. Dalam proses dekomposisi, karbon digunakan sebagai sumber energi untuk menyusun bahan seluler sel-sel mikroba dengan membebaskan $\mathrm{CO}^{2}$ dan bahan lain yang menguap.
Kadar C-Organik tertinggi terdapat pada perlakuan $\mathrm{P} 4$ (2 $\mathrm{kg}$ pelepah dan $0,4 \mathrm{~kg}$ bungkil jagung) dengan nilai $40,11 \%$ dan yang terendah terdapat pada perlakuan $\mathrm{P} 4$ ( $2 \mathrm{~kg}$ pelepah dan $0,8 \mathrm{~kg}$ bungkil jagung) dengan nilai $37,27 \%$. Semua kompos pelepah kelapa sawit tidak sesuai standar SNI kompos dengan kadar C-Organik 9,8$32 \%$.

Adapun perbedaan hasil P0, P1, P2, P3, P4 analisa kadar C-Organik dapat dilihat pada Gambar 1 di bawah ini:

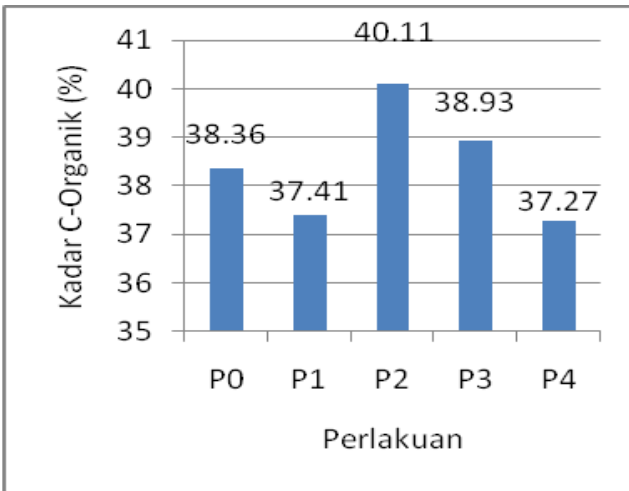

Gambar 1. Kadar C-Organik Kompos Pelepah Kelapa Sawit.

\section{Kadar N (Nitrogen) Kompos Pelepah Kelapa Sawit.}

$\begin{array}{ccr}\text { Menurut } & \begin{array}{c}\text { Starbuck, } \\ \text { bertugas } \\ \text { organisme yang } \\ \text { menghancurkan }\end{array} & \begin{array}{r}\text { (2004) } \\ \text { dalam } \\ \text { organik }\end{array}\end{array}$
membutuhkan $\mathrm{N}$ (nitrogen) dalam jumlah yang besar. Nitrogen akan bersatu dengan mikroba selama proses penghancuran material organik. Setelah proses pembusukan selesai, nitrogen akan dilepaskan kembali sebagai salah satu komponen yang terkandung dalam kompos.

Kadar $\mathrm{N}$ tertinggi terdapat pada perlakuan P3 (2 kg pelepah dan $0,6 \mathrm{~kg}$ bungkil jagung) dengan nilai 2,61\% dan yang terendah terdapat pada perlakuan P1 $(2 \mathrm{~kg}$ pelepah) dengan nilai 1,97\%. Kadar N pada semua perlakuan telah memenuhi SNI 197030-2004 yaitu dengan kadar $\mathrm{N}>0,40 \%$. 
Untuk mengetahui lebih jelas perbedaan kadar $\mathrm{N}$ P0, P1， P2, P3,P4 kompos pelepah kelapa sawit pada setiap perlakuan dapat dilihat pada gambar 4.4 dibawah ini :

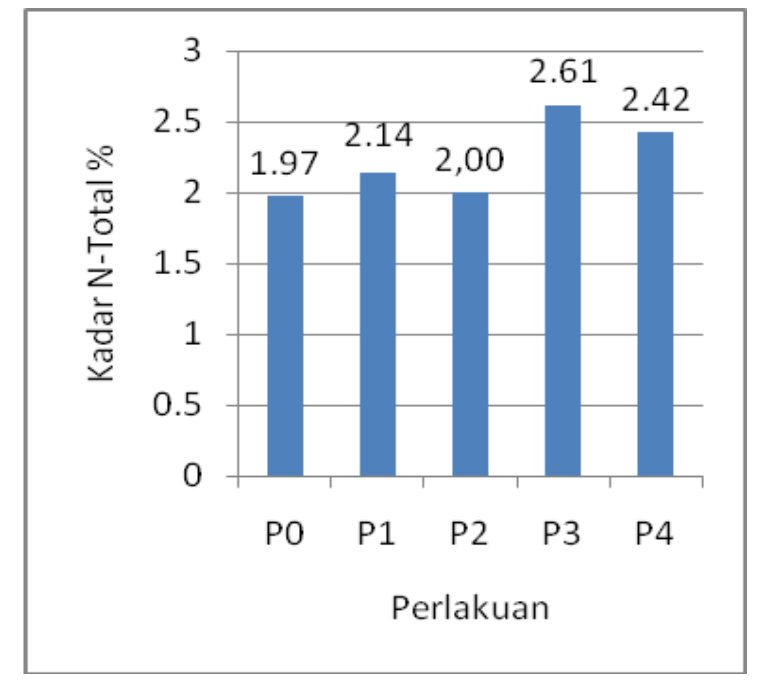

Gambar Kadar N-Total Kompos Pelepah Kelapa Sawit.

Kadar nitrogen dibutuhkan mikroorganisme untuk memelihara dan pembentukan sel tubuh. Semakin banyak kandungan nitrogen, maka akan semakin cepat bahan organik terurai, karena mikroorganisme yang menguraikan bahan kompos memerlukan nitrogen untuk perkembangannya (Srihartati, 2008).

\section{Kadar Rasio C/N Kompos Pelepah Kelapa Sawit.}

Menurut Hanafi (2005) Kompos yang memiliki nilai $\mathrm{C} / \mathrm{N}$ kurang dari 20 berarti unsur-unsur hara pada limbah organik tersebut telah mengalami penguraian dan mineralisasi sehingga menjadi tersedia dan dapat diserap oleh akar tanaman.

Rasio $\mathrm{C} / \mathrm{N}$ tertinggi terdapat pada perlakuan P2 (2 kg pelepah dan 0,4 bungkil jagung) dengan nilai $20,10 \%$. Dan yang terendah terdapat pada perlakuan P3 ( $2 \mathrm{~kg}$ pelepah dan $0,6 \mathrm{~kg}$ bungkil jagung) dengan nilai $14,92 \%$. Rasio C/N pada semua perlakuan telah memenuhi standar yaitu dengan nilai $10-20 \%$.

Untuk mengetahui lebih jelas perbedaan kadar Rasio C/N P0, P1, P2, P3,P4 kompos pelepah kelapa sawit pada setiap perlakuan dapat dilihat pada gambar 4.5 dibawah ini :

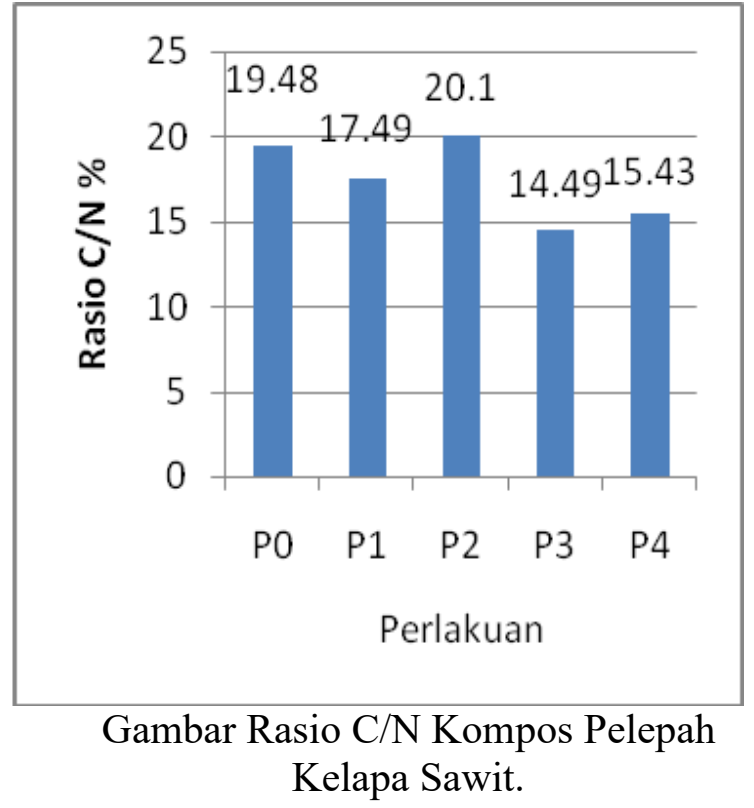

Rasio $\mathrm{C} / \mathrm{N}$ yang terlalu tinggi akan memperlambat proses pembusukan, sebaliknya jika terlalu rendah walaupun awalnya proses pembususkan berjalan dengan cepat, tetapi akhirnya melambat karena kekurangan $\mathrm{C}$ sebagai sumber energi bagi mikroorganisme (Pandebesie, 2012).

\section{KESIMPULAN}

Kesimpulan yang didapat dari hasil penelitian ini adalah :

1. Suhu optimal pengomposan pada penelitian ini yaitu $30-38^{\circ} \mathrm{C}$, hal ini masih sesuai standar suhu optimal yaitu $30-50^{\circ} \mathrm{C}$, sedangkan menurut kriteria SNI (BSN 2004), suhu ideal proses pengomposan maksimal $50^{\circ} \mathrm{C}$.

2. $\mathrm{pH}$ optimal pada penelitian yaitu $6,26-$ 7,82, hal ini disebabkan karena $\mathrm{pH}$ mengalami peningkatan dan penurunan 
merupakan penanda terjadinya aktivitas miroorganisme dalam menguraikan bahan organik.

3. Kadar C-Organik paling tinggi yaitu terdapat pada perlakuan P2 (2 kg pelepah dan $0,4 \mathrm{~kg}$ bungkil jagung) dengan nilai $40,11 \%$ dan perlakuan terendah pada perlakuan P4 (2 kg pelepah dan $0,8 \mathrm{~kg}$ bungkil jagung) dengan nilai $37,27 \%$. Semua perlakuan tidak sesuai standar SNI kompos dengan kadar C-Organik 9,8-32\%.

4. Kadar $\mathrm{N}$ paling tinggi terdapat pada perlakuan P3 (2 kg pelepah dan $0,6 \mathrm{~kg}$ bungkil jagung) dengan nilai 2,61\%. Hal ini telah memenuhi SNI 19-7030-2004 yaitu dengan kadar $\mathrm{N}>0,40 \%$.

5. Rasio C/N sesuai standar SNI yaitu 10$20 \%$. pada penelitian ini semua perlakuan sesuai standar tidak ada < $10 \%$ dan tidak ada $>20 \%$.

\section{DAFTAR PUSTAKA}

Astri L. P. 2011. Kualitas pupuk kompos bedding kuda dengan menggunakan aktivator mikroba yang berbeda. Skripsi. IPB. Bogor.

Buckman, H. O. dan Brady, N. C. 1982. Ilmu Tanah. Bhratara Karya Aksara. Jakarta.

Direktorat Jenderal Perkebunan, 2017. Statistik Perkebunan Indonesia 2015 - 2017 Kelapa Sawit. Jakarta (ID): Direktorat Jenderal Perkebunan, Depertemen Pertanian. 2017: hal. 911.

Epstein, E. 1997. The Science of Composting. Thechnomic Pennsylvania Lancaster: Publishing Inc.

Fanny, R. 2013. Pemanfaatan Blotong sebagai Aktivator Pupuk Organik. Program Studi Teknik Lingkungan. Universitas Pembangunan Nasional. Jatim.
Firdaus F. 2011. Kualitas pupuk Kompos Campuran Kotoran Ayam dan Batang Pisang menggunakan bioaktivator MOL tapai. Skripsi. IPB. Bogor.

Hanafi, K. A. 2005. Dasar-dasar Ilmu Tanah. Jakarta : Raja Grafindo Persada.

Indriani, Y. H., 2007. Membuat Pupuk Organik Secara Singkat. Jakarta: Penebar Swadaya.

Isroi. 2008. Kompos. Makalah. Balai Penelitian Bioteknologi Perkebunan. Bogor.

Jeremi, M. S. 2018. Pemanfaatan Limbah Padat Palm Kernel Cake (PKC) Dalam Pengomposan Pelepah kelapa Sawit. STIPAP. Medan.

Marlina E.T. 2009. Biokonversi Limbah Industri Peternakan, Bandung: UNPAD PRESS

Mirwan, M. 2015. Optimasi Pengomposan Sampah Kebun Dengan Variasi Aerasi Dan Penambahan Kotoran Sapi Sebagai Bioaktivator.

Pandebesie, E. S. 2012. Pengaruh Penambahan Sekam Padi Proses Pengomposan Sampah Domestik. Jurnal Lingkungan Tropis.

Risza S. 2010. Masa Depan Perkebunan Kelapa Sawit di Indonesia. Yogyakarta (ID) :Penerbit Kanius. 272 hal.

Srihartati, 2008. Pemanfaatan Limbah Pisang Untuk Pembuatan Pupuk Kompos Menggunakan Kompos Rotary Drum. Yogyakarta.

Straburck, C. J. 2004. Waste Managemen Alternative: Composting. Universty of Nottingham School of Biocience, Scientific Program, Nottingham. 
Wahyono, S., L. Firman, Sahwan, F. Suryanto. 2011. Membuat Pupuk Organik Granular dari Aneka Limbah. Agromedia Pustaka, Jakarta.

Yuwono, 2007. Kompos. Penebar Swadaya, Jakarta. 